\title{
On some Species of the Ostracode Genus Polycope from Baluti Formation (Upper Triassic), Northern Iraq
}

\author{
Sanad A. Al-Khashab \\ Department of Geology \\ College of Science \\ University of Mosul
}

\author{
Jawaher M. Al-Halawachi \\ Department of Geology \\ College of Science \\ University of Mosul
}

(Received 15/5/2013 ， Accepted 30/9/2013)

\begin{abstract}
Five ostracode species belong to the genus Poloycope have been described from Baluti Formation (Upper Triassic) of North Iraq, these are: $P$. aghdarbandens Tollman 1991, P. bourquinaeCrasquin and Gradinaru 1996, P. spp. Forel and Crasquin 2011, P. sp.A Rosenfeld and Honigstein 1998 and P. sp. Monostori 1996.

Keywords: Ostracode, Polycope, Baluti Formation, Upper Triassic, North Iraq.

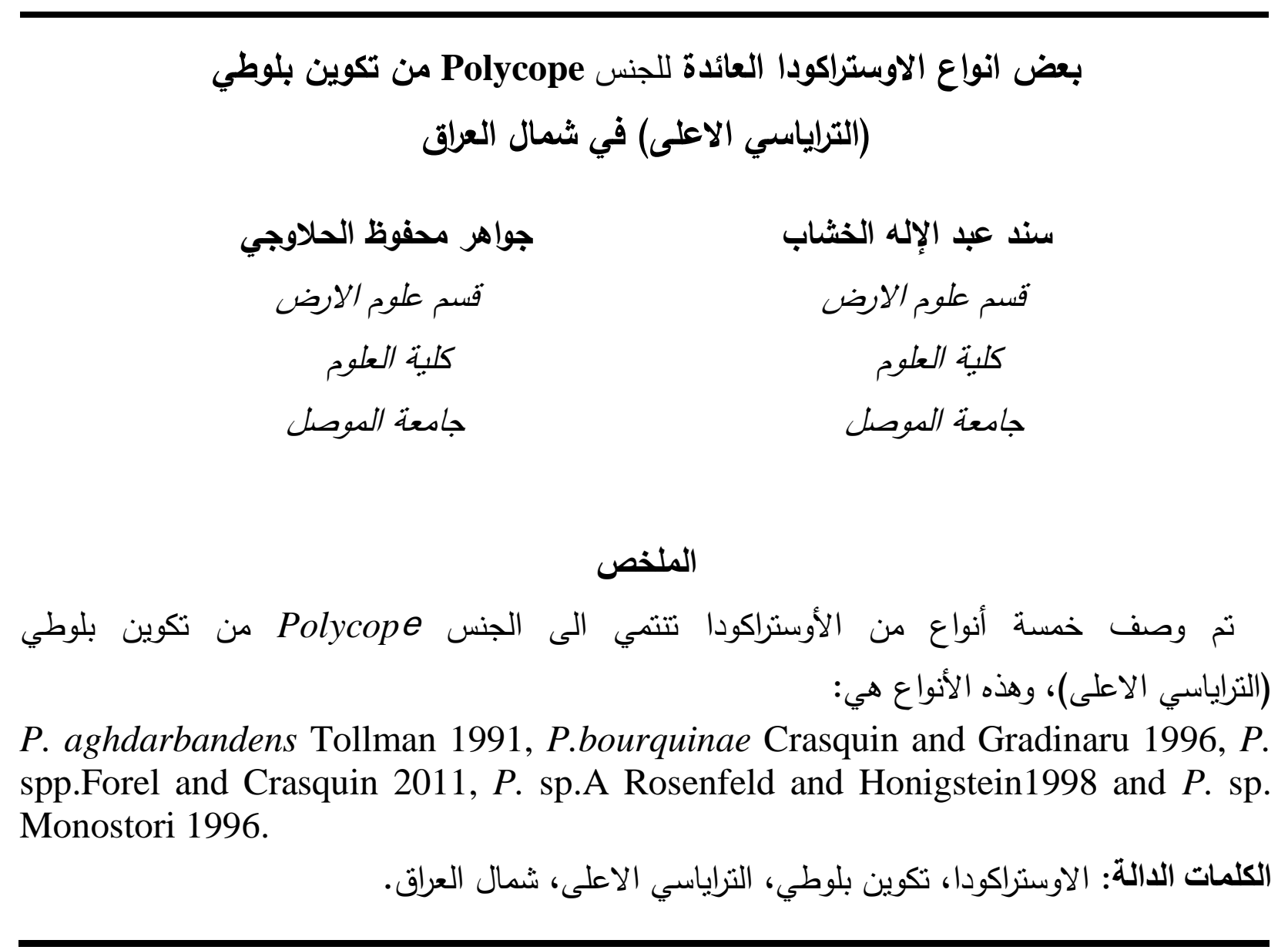




\section{LOCATION}

The studied area located within Dohuk province, northern Iraq, (11) km southeastern Amadiya city, close to the Sarki village and within the coordinates $36^{\circ} 59^{\prime} 30$ "north and 43 $32^{\prime} 20^{\prime \prime}$ east within the core of Gara anticline (Fig. 1), also (Fig. 2) illustrated the studied area within the core of Gara anticline.

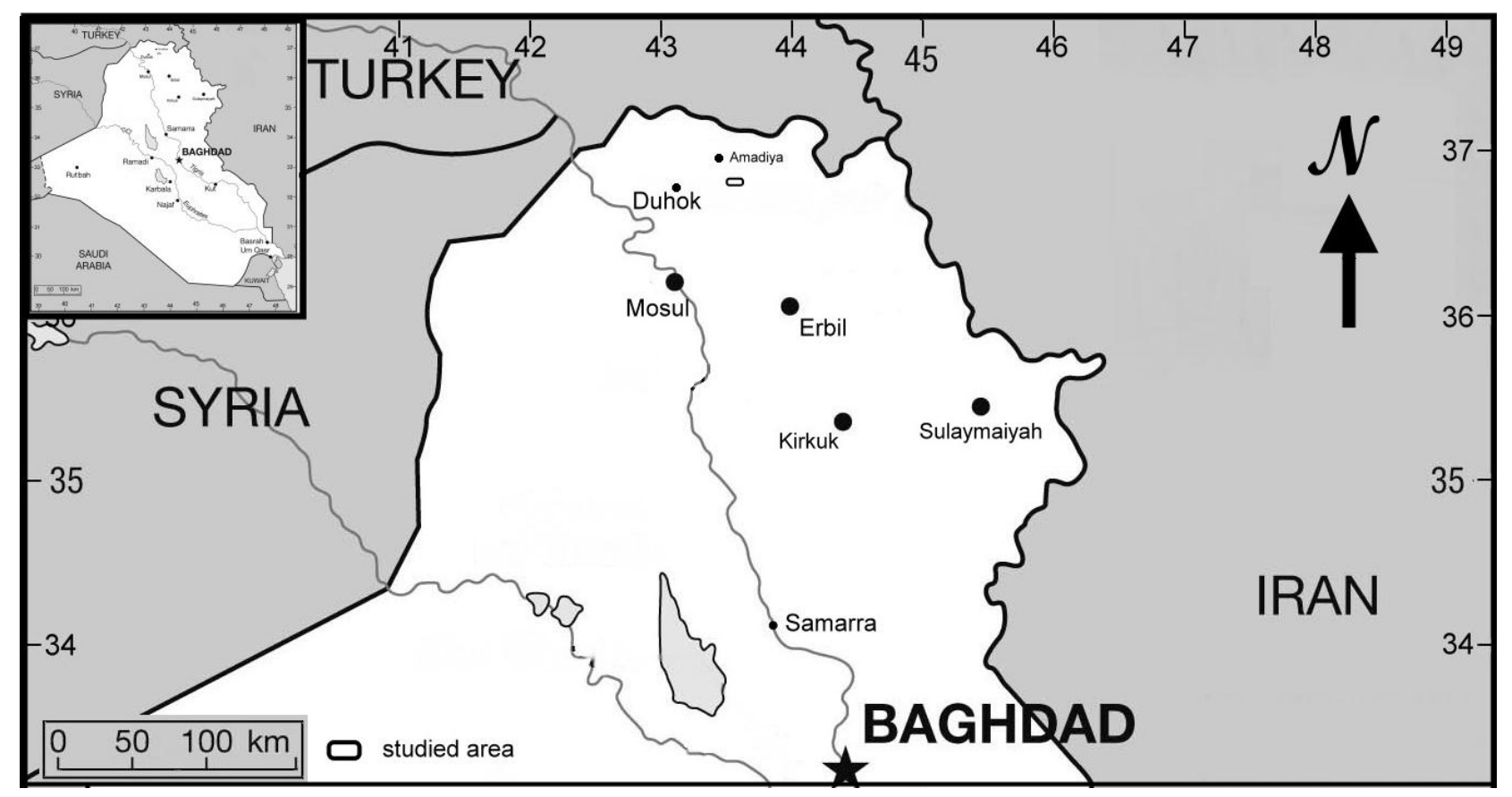

Fig. 1: Iraq Map, Showing the Location of the Studied Area.

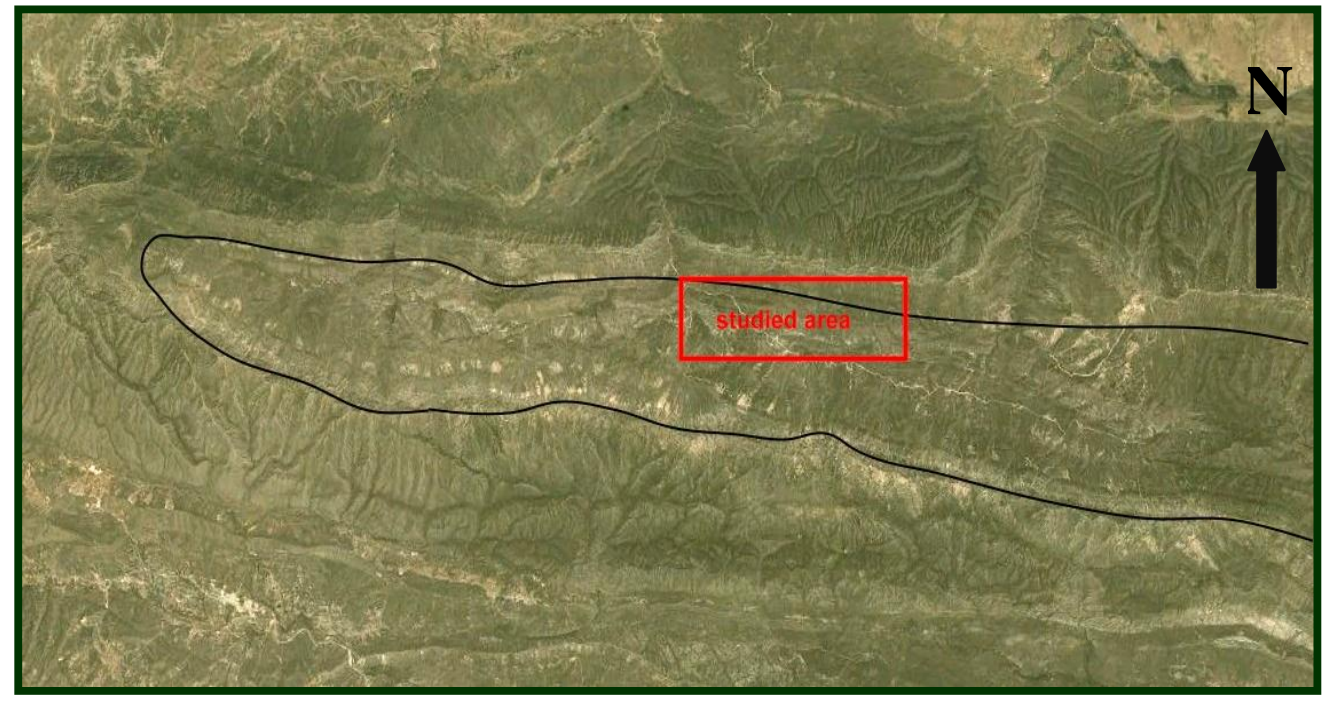

Fig. 2: The Core of Gara Anticline, Southeast of Amadiya City, Showing the Location. 


\section{INTRODUCTION}

The lithology of the Baluti formation is identical to that of the type section in the Balambo-Tanjero of High Folded Zones (Bolton, 1958 in Bellen et al., 1959). Samples were collected from Baluti Formation shown in (Fig. 3), the genus Polycope were found in samples 4 and 5.

In the present study, the formation at the studied location is about $(32.4 \mathrm{~m}$.) in thickness based on the measurements in the field. Lithologically the lower part consists of shale, dark grey, yellowish green marl, limestone, brownish yellow color, shale yellowish color became at the top dark grey to black color (fissility), recrystallized carbonate, dark grey color divided into (3) beds with $25 \mathrm{~cm}$ thick, brown carbonate collapse breccias, black shale. Upper part consists massive bedded carbonate with lenses of shale, yellowish coloursome time specially at the top silty carbonate, carbonate yellowish grey color mottled by shale which disappearance at the top of carbonate beds, with shale, yellow to light grey bed with a thick of 10 to $15 \mathrm{~cm}$, Interbeded with shale black fissility, dark brown carbonate, to yellow color recrystallized lime. Both lower and upper boundaries of the formation are conformable and gradational (Bellen et al., 1959) except in well Tharthar-1.The conformable nature of upper contact of the formation in some parts of Iraq (Ga'ara area, western Iraq) seems to be uncertain, due to the ascertained break between Triassic and Liassic, and the widespread and well known break between Triassic and Liassic in Saudi Arabia, southwestern Iran ...etc. (Buday, 1980).

The present work is part of M.Sc. Project investigating ostracode microfossil from Baluti Formation (Upper Triassic) from Amadiya section, at Geology Dept., Mosul University. All the Figured specimens are deposited at Mosul university with prefix (MUTBO) which is came from (MU =Mosul University, $\mathrm{T}=$ Triassic, $\mathrm{B}=$ Baluti Formation and $\mathrm{O}=$ Ostracoda $)$.

\section{PREPARATION OF SAMPLES}

Sample were collected from Baluti Formation outcrop section in Amadiya area of northern Iraq, has processed the arrogance traditional practices. (24) sample has been washed. There are several different methods used by type rock, in general, toextract microfossils from the sediments, different methods were used on the basis of lithological type. The sample was first weighed and soft sediment boiled in water with some amount of Sodium Carbonate, Boiling and sieving repeated many times until clean residue was obtained. Hard sample, were heated on electric iron plate, cooked the soalcad with Kerosene, then uses the above method many times with sodium carbonate to get residue.

A soft brush was used to pick ostracode specimens the microscope binary and strongly zoom lens $(25 \mathrm{X})(40 \mathrm{X})$. After that was filmed samples to make modifications to the microscope (OPTIKA, B-35POL) where the shed and multiple external lighting units and photographed samples under zoom (40X). 


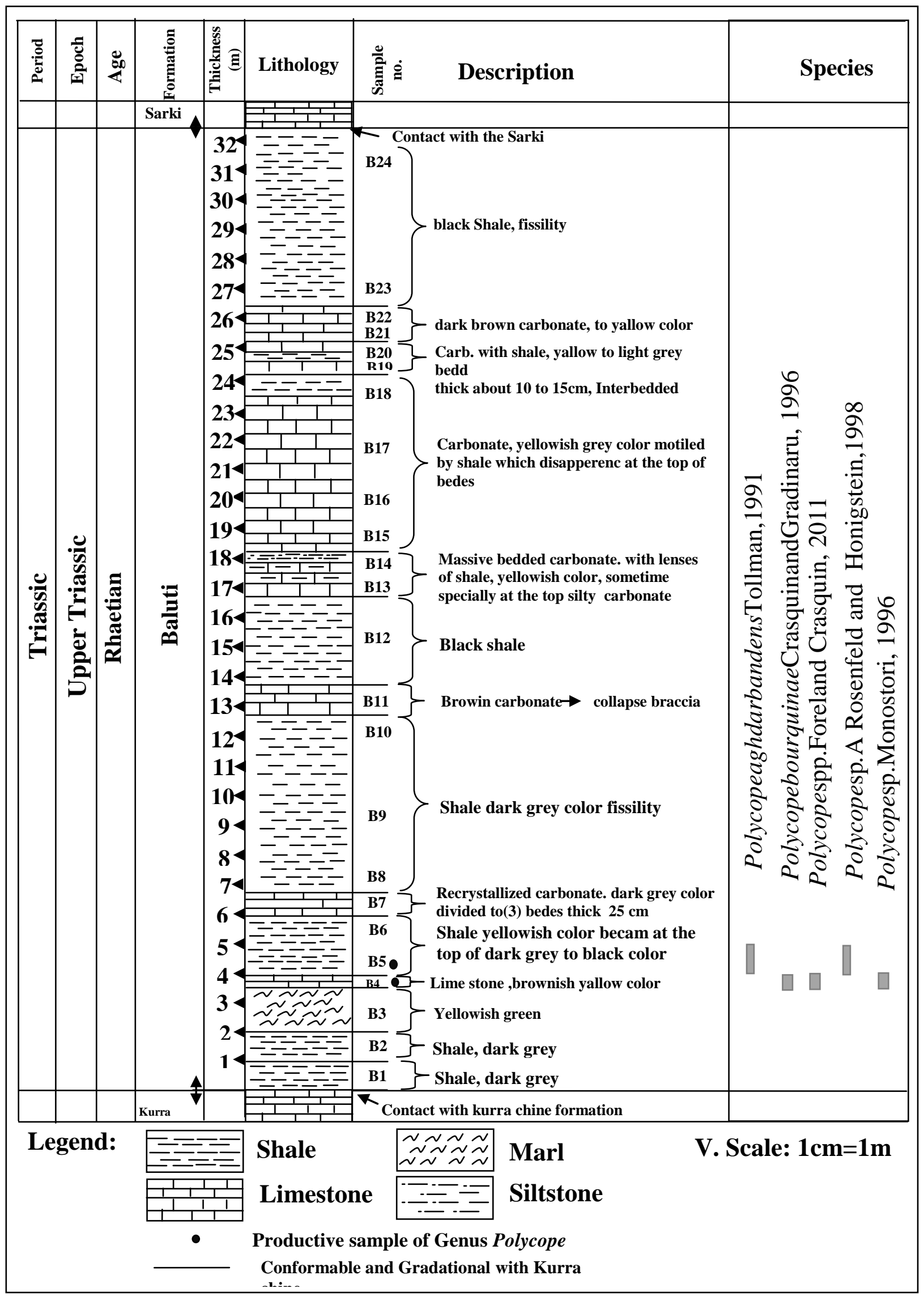

Fig. 3: Lithological Section of Baluti Formation, Northern Iraq. 


\section{SYSTEMATIC DESCRIPTION}

Phylum CRUSTACEA Pennant, 1777

Class OSTRACODA Laterille, 1806

Subclass PODOCOPA Muller, 1894

Order MYODOCOPIDA Sars, 1866

Suborder CLADOCOPINA Sars, 1866

Family POLYCOPIDAE Sars, 1866

Genus Polycope Sars, 1866

Type species: polycope orbicularis SARS 1866, P. 122

Polycope aghdarbandens Tollman, 1991

(pl.1, Fig.1)

1991 polycope aghdarbandens Tollman, p.197, pl.1, Figs.(10 - 12).

Material: one carapace.

Occurrence: Baluti Formation, Gara anticline, sample, No. 5.

Dimensions (um): Length: 600, Height: 590, L/H: 1.016, Carapace (RV)MUTBO1:1

Description: Carapace semicircular, ornamentation vinaigrette, which run anteroventrally parallel with the border of the carapace in a U-shaped form and are open posterodorsally.

Remarks: The Iraqi specimens identical to the species Polycope aghdarbandens Tollman, p.197, pl.1, Fig.(10 - 12) from Upper Ladinian, NE-Iran, but differ of shape and ornamentation.

\section{Polycope bourquinae Crasquin and Gradinaru, 1996}

(Pl.1, Fig. 2)

1985Polycopesp.Bunza and Kozur, p. 15, pl. II, Fig. 12.

?1993 Polycopsissp. Mirauta, Gheorghian and Badiceanu, pl.III, Fig.17a ,b.

1996 Polycope bourquinaesp. Crasquin and Gradinaru, p.16, pl.1, Fig. 4 - 6

Material: one carapace.

Occurrence: Baluti Formation, Gara anticline, sample No. 4

Dimensions (um): Length: 400, Height: 390, L/H: 1.025, Carapace

(RV)MUTBO1:2 
Description: Carapace circular, surface is dotted ornamentation, carapace compressed laterally along all the margins.

Remarks: The Iraqi specimens identical to the species Polycope bourquinaesp. Crasquin and Gradinaru, p.16, pl.1, Fig 4 - 6. from Early Middle Triassic of Cimmerian north Dobrogean Orogen, Romania, but the Iraqi type differ from the Romanian type by the absence of ornamentation.

Polycope spp. Forel and Crasquin, 2011

(pl.1, Fig. 3)

2011 polycopespp. Forel and Crasquin, p. 463, Fig. 4A

Material :one carapace.

Occurrence: Baluti Formation, Gara anticline, sample, No.4.

Dimensions (um):Length: 300, Height: 300, L/H: 1, Carapace (RV)MUTBO1:3

Description: Carapace circular, and smooth surface with generally no clue as to orientation.

Remarks: The Iraqi specimens completely identical with Polycope spp. Forel and Crasquin,2011, p.463, Fig. 4A. Lower Triassic ostracods (Crustacea) from the Meishan section, Permian - Triassic boundary GSSP (Zhejiang Province, South China)

Polycope sp. A Rosenfeld and Honigstein, 1998

(Pl.1, Fig. 4)

1998 Polycope sp. A Rosenfeld and Honigstein, P. 84, pl. 2, Fig. 11.

Material: one carapace.

Occurrence: Baluti Formation, Gara anticline, sample, No.5.

Dimensions(um):Length: 400, Height: 400, L/H: 1, Carapace (RV)MUTBO1:4

Description: Carapace circular, ornamentation vinaigrette, pronounced all over the carapace.

Remarks: The Iraqi specimens identical to the species Polycope sp. A Rosenfeld and Honigstein, 1998, P.84, pl.2, fig.11.from Kimmeridgian of Israel, but differ of shape and Ornamentation.

Polycope sp. Monostori,1996

(pl.1, Fig. 5)

1996Polycopesp. Monostori, p. 34, pl. 1, Fig. 1. 
Material: one carapace.

Occurrence: Baluti Formation, Gara anticline, sample No. 4.

Dimensions(um): Length: 420, Height: 420, L/H: 1, Carapace (RV)MUTBO1:5

Description: Carapace semicircular, this species is generally smooth.

Remarks: The Iraqi specimens identical to the species Polycope sp. p. 34, pl. 1, Fig. 1. from Late Triassic of the Bakony Mts. (Transdanubian Central Range, Hungary), but differ of shape.

\section{REFERENCES}

Bellen, R. C., Van, Dunnington, H. V., Wetzel, R. and Morton, D., 1959. Lexique Stratigraphique International Asie, Iraq. Intern. Geol. Conger. Comm. Stratigr. 3, Fasc.10a. p. 333.

Buday, T., 1980. The Regional Geology of Iraq. Vol.1: Stratigraphy and Palaeogeography. Publications of GEOSURV., Baghdad, p. 445.

Crasquin, S.and Gradinaru., 1996. Early Anisianostracode Fauna from the Tulce Unit (Cimmerian North Dobrogean Orogen, Romania). Annales de Paleontologie, Vol. 82, fasc. 2, pp. 59 - 11.

Forel M. B. and Crasquin, S., 2011. Lower Triassic Ostracoda (Crustacea) from the Meishan Section, Permian - Triassic Boundary GSSP (Zhejiang Province, South China). Journal of Systematic Palaeontology, Vol. 9, Issue 3, pp. 445 - 466.

Kozur, H.,1985. Neue Ostracoden - Artenausdem Oberen Mittelkarbon (Hoberes Moskovian), Mittel. - und Oberperm des Bukk. - gebirges (N.- Ungarn). Geol. Palaont. Mitt. Ibk., 2: pp. 1 - 145.

Mirauta E., Gheorglan D. and Badiceanu M., 1993. Donnees biostratigraphy quessur la Formation de Cataloi (Dobrogea du Nord, Roumanie). Rom. J. Stratigraphy, 75: pp. $21-27$.

Monostori, M., 1996. Pliensbachian Ostracod Fauna from Condensed Limestones of the Bakony Mts. (Transdanubian Central Range, Hungary). Fragm. Min. ET Pal., pp. 31 - 61.

Rosenfeld, A. and Honigstein, A., 1998. Kimmeridgian Ostracodes from The Haluza Formation in Israel. Revista Espanola Micropaleontologia, Vol. 30, No. 2, pp. 77 - 87.

Tollmann, K.,1991. Ostracoda from the Middle Triassic Sina Formation (Aghdarband Group) in North Iran. - Abh. Geol, B. - A., Band 38., pp. 195 - 200. 


\section{PLATE 1}

1- Polycope aghdarbandens Tollman,1991. Carapace (RV)MUTBO1:1

2- Polycope bourquinae Crasquin and Gradinaru ,1996.Carapace (RV)MUTBO1:2

3- Polycope spp. Forel and Crasquin, 2011.Carapace (RV)MUTBO1:3

4- Polycope sp.A Rosenfeld and Honigstein,1998.Carapace (RV)MUTBO1:4

5- Polycope sp. Monostori, 1996. Carapace (RV)MUTBO1:5

\section{PLATE 1}

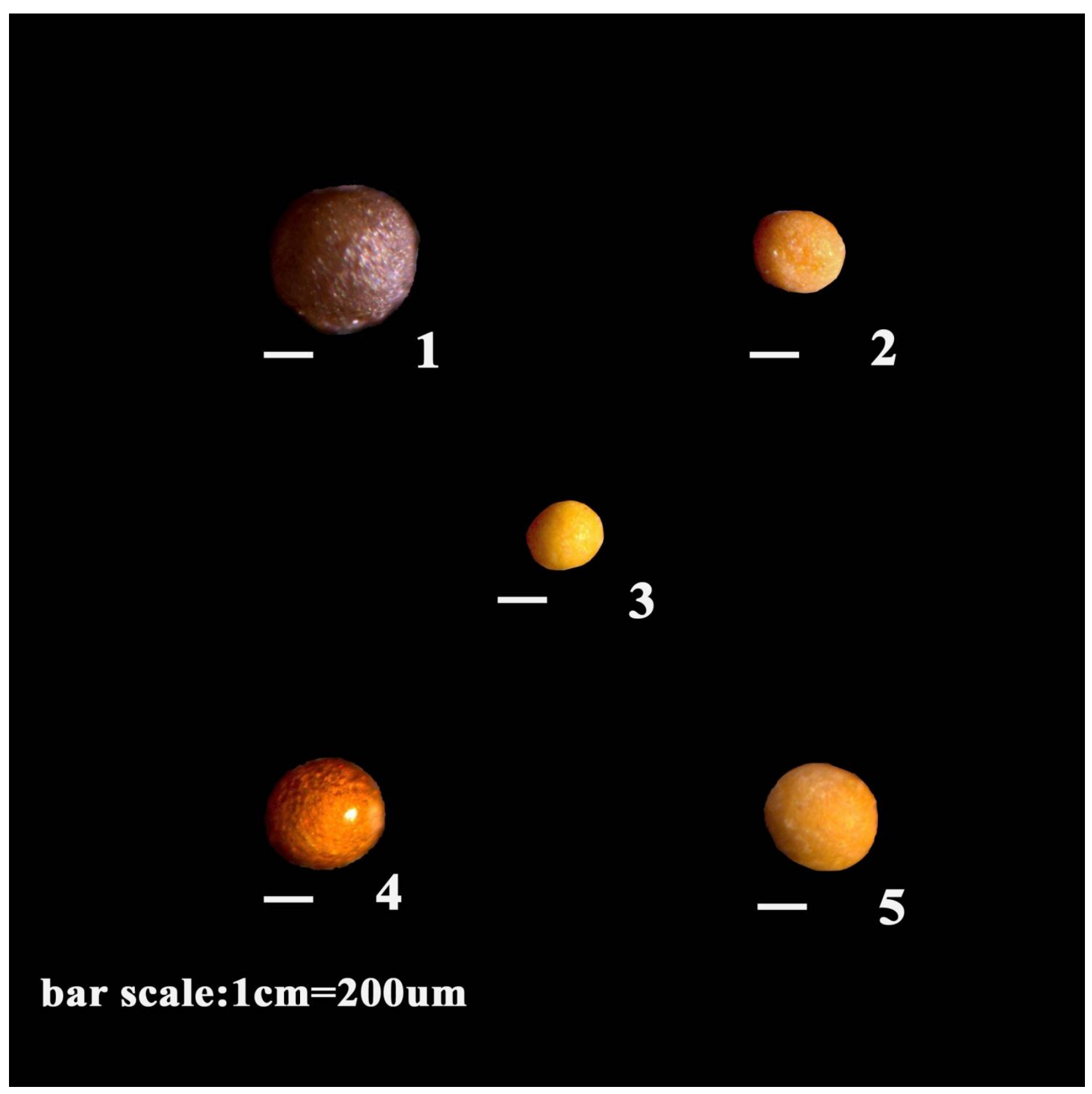

